\title{
Василь МOPO3
}

\section{ТЕОРЕТИКО-ОРГАНІЗАЦІЙНІ ОСНОВИ ФІНАНСОВОГО РЕГУАЮВАННЯ ЗЕМЕАЬНИХ ВІДНОСИН В УКРӒ̈̈Н}

Розглянуто теоретико-організаційні засади фрінансового регулювання земельних відносин в Україні. Висвітлено актуальні питання і напрями удосконалення їх фінансового регулювання й оптимального поєднання з ринковим саморегулюванням, а також визначено необхідні умови щодо реалізації цих можливостей. Зроблено висновки щодо підвищення ефективності методів фінансового регулювання земельних відносин, створення фонду земель державної власності в Україні.

Ключові слова: земельні відносини, земельна рефрорма, фрінансове регулювання, державна політика, оренда, орендні відносини.

\section{Василий MOPO3}

Теоретико-организационные основы финансового регулирования земельных отношений в Украине

Рассмотрены теоретико-организационные основы финансового регулирования земельных отнощений в Украине. Освещены актуальные вопросы и направления совершенствования их финансового регулирования и оптимального сочетания с рыночным саморегулированием, а также определены необходимые условия для реализации этих возможностей. Сделаны выводы по повышению эффрективности методов фринансового регулирования земельных отномений, создания фонда земель государственной собственности в Украине.

Ключевые слова: земельные отношения, земельная реформа, фринансовое регулирование, государственная политика, аренда, арендные отношения.

\section{Vasyl MOROZ}

Theoretical and organizational basis of financial regulation of land relations in Ukraine

Introduction. In modern conditions the problem of the land relations arrangement in Ukraine is extremely important, because the development of the economy sector depends on its solution. The fact that Ukraine is an agrarian country and one of the most fertile land in the world, actualizes the issue of creating an effective mechanism of land relations, which would stimulate the most effective increase of the country budget. In fact, this is the main task of financial regulation in Ukraine.

(๑) Василь Мороз, 2017 
The issues of developing the rent land relations concerning formation of market value of land as an effective factor of economic development, working mutually beneficial rules out of the game between tenants and land owners, establishing the optimal amount of rent, forms of its payment and terms of lease require further research.

Purpose. The purpose of this article is formulation the ways to solve the problem of financial regulation in Ukraine.

Results. This research gives a concept of renting. It allows reaching the optimum amount of land use without advancing funds for purchase of land, because expenses will not pay for itself at rather low income level soon.

Conclusion. This research suggests the following conclusions and recommendations for improving the financial regulation of land relations in Ukraine:

- the role of the state should be decisive in land regulation

- it is necessary to carry out activities aimed at creation of effective and adjustable land turnover

- financial regulation of property relations should be improved it is necessary to create a fund of state-owned land.

Keywords: land relations, land reform, financial regulation, state policy, rent, rent relations.

JEL Classification: L51, Q15, R14, R38.

Постановка проблеми. Зростаюча потреба у забезпеченні сталого розвитку наполегливо вимагає від держави та українського суспільства загалом принципово нового ставлення до питання формування та реалізації фрінансового регулювання земельних відносин. Ситуація стосовно земельних відносин і землекористування залишається складною і такою, що вимагає невідкладного вирішення. Модернізація фрінансового регулювання зумовлена тим, що земельна реформа, яка розпочалася з прийняття Постанови Верховної Ради Української РСР "Про земельну ресрорму" від 18.12.1990 р. та продовжується вже 27-й рік, так і не вирішила поставлених перед нею завдань.

Оскільки процеси земельного реформування відбувалися повільно, земельне питання стало вкрай політизованим, а шляхи переходу землі до ефективних землекористувачів були практично заблоковані. На жаль, побудована в Україні система фінансового регулювання у зазначеній сфрері $\epsilon$ внутрішньо-суперечливою, незавершеною, громіздкою і виступає гальмом у проведенні завершального етапу земельної реформи.

Аналіз останніх досліджень і публікацій. Слід визнати, що реалізація земельної політики в Україні нерідко здійснюється без необхідного науково-теоретичного фундаменту, оскільки до цього часу в суспільстві немає єдності поглядів щодо головних принципів, економічних важелів та обмежень стосовно впровадження ринкових земельних відносин в Україні. Сучасні теоретичні положення стосовно економічного регулювання у сфрері земельних відносин знайшли відображення в дослідженнях таких економістів, як: О. Бречко [2], П. Герасим [16], Н. Демчишак [1], І. Чугунов [3], Л. Новаковський [5], Б. Пасхавера [15], М. Присяжнюк [10; 14], В. Сафранов [13], А. Третяк [9], Н. Третяк [17], В. Федосов [4], М. Федоров [12], С. Юрій та інші. Водночас залишається дискусійним широке коло питань щодо подальшого розвитку фінансо- 
вого регулювання в Україні, які значною мірою впливають на формування земельних відносин і запровадження сталого землекористування, підвищення есрективності використання й охорони земельних ресурсів, інвестиційної привабливості земель.

Мета статті полягає у дослідженні теоретико-концептуальних засад розвитку земельних відносин в Україні та розробці пропозицій щодо підвищення ефективності фрінансового регулювання таких відносин у сучасних умовах.

Виклад основного матеріалу дослідження. Ефективне фрінансове регулювання земельних відносин є невід'ємною складовою державного управління соціально-економічним розвитком України, створює важливі умови для розвитку інфрраструктури та життєдіяльності суспільства, відіграє вагому роль у наповненні державного і місцевих бюджетів.

В сучасних наукових джерелах фрінансове регулювання розглядається науковцями з різних точок зору. Відтак, для детального вивчення цієї проблематики доцільно розглянути різні тлумачення цього поняття.

Вітчизняні вчені С. Огородник, В. Опарін, В. Суторміна В. Федосов, виокремлюють фінансове рулювання як складову (підсистему) фінансового механізму, що характеризує вплив фрінансів на соціально-економічні процеси, а його використання залежить від фрінансової політики в державі та обумовлене конкретною ситуацією [1, с. 89].

О. Бречко трактує фрінансове регулювання, як метод управління економічними та соціальними процесами за допомогою фінансів, основою якого, як підсистеми фінансового механізму, $є$ правове регламентування розподільчих відносин у суспільстві, в окремих галузях і сфрерах державного регулювання, на окремих підприємствах [2].

І. Чугунов зауважує, що змістом фрінансового регулювання $\epsilon$ розроблення осно- вних напрямів формування та використання фінансових ресурсів, відповідно до необхідності завдань, які стоять перед суспільством на певному етапі його розвитку [3, с. 536].

Змістовним, на нашу думку, $€$ визначення поняття фрінансового регулювання, запропоноване С. Юрієм та В. Федосовим. Науковці трактують його як сукупність розподільчих та перерозподільчих заходів, які держава здійснює через фінансову систему щодо використання фінансових відносин з метою забезпечення зростання ВВП та підвищення рівня добробуту всіх членів суспільства [4, с. 245].

Узагальнюючи підходи до тлумачення сутності фінансового регулювання, зазначимо, що цей термін можна розглядати 3 двох позицій:

- фінансове регулювання як складова реалізації фінансової політики;

- фінансове регулювання як елемент державного регулювання.

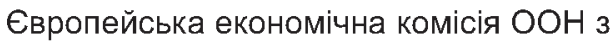
питань управління земельними ресурсами наводить рекомендації, які дають змогу забезпечити належне фрінансове управління ними, зокрема:

- визначення на законодавчому рівні сутності, форм і характеру власності на землю, фрорм користування і прав на неї, обмежень і зобов'язань, які треба реєструвати

- комерційне використання системи управління земельними ресурсами відповідно до довгострокової фрінансової стратегії, системи нормативно-правового регулювання та адміністративного управління, а також орієнтації системи управління земельними ресурсами на задоволення попиту споживачів;

- забезпечення прозорості діяльності системи управління земельними ресурсами, надійного та вільного доступу до земельної інфрормації всіх суб'єктів ринку; 
- проведення постійного моніторингу, оцінки та здійснення контролю за ефективністю, цілісністю і прозорістю системи управління земельними ресурсами 3 урахуванням показників, що відображають, зокрема, витрати коштів і часу на виконання кожної операції із землею, а також ступінь задоволення потреб [5].

На жаль, змушені констатувати, що в сучасних умовах державну земельну політику можна вважати такою, що перебуває на стадії формування та не повною мірою відповідає європейським і світовим критеріям і вимогам щодо належного управління земельними ресурсами. На сьогодні в Україні немає затвердженої на законодавчому рівні загальної стратегії розвитку земельних ресурсів і земельних відносин.

Згідно зі Стратегією сталого розвитку "Україна-2020" основними напрямками розвитку земельних відносин є: повна персоніфікація власників і користувачів земельних ділянок сільськогосподарського призначення; створення державної системи реєстрації прав власності на земельні ділянки та розміщене на них нерухоме майно; удосконалення методики оцінки земель, урахування вартості землі сільськогосподарського призначення при збалансуванні міжгалузевих відносин; формування інфрраструктури ринку землі; створення системи земельного іпотечного кредитування; упровадження і фрінансове забезпечення загальнодержавних програм використання та охорони земель, зокрема зменшення їх розораності, системи захисту від водної і вітрової ерозії, відтворення і підвищення родючості ґрунтів, агролісомеліорації та меліорації земель, рекультивації порушених земель, стандартизації та нормування $\mathrm{y}$ сфері охорони земель; включення проектів організації територій новостворених землеволодінь та землекористувань до бізнеспланів відповідних сільськогосподарських підприємств; запровадження ефективної системи охорони родючості ґрунтів та системи моніторингу ґрунтів, проведення суцільної агрохімічної паспортизації земель сільськогосподарського призначення [6].

Незважаючи на те, що існує багато програм і завдань, які безпосередньо або опосередковано стосуються окремих проблем земельної політики, земельні відносини в Україні, на жаль, залишаються ще не до кінця врегульованими, адже, як справедливо зазначає Л. Новаковський, повноцінного правового поля для регулювання земельних відносин до цього часу не створено. Особливу увагу він акцентує на перебудові системи контролю за використанням і охороною земель, оскільки державний контроль, що здійснюється, є неефективним, кількість порушень законодавства постійно зростає, земельні органи нерідко самі порушують закони, а держава не має ефективного впливу на порушників - державних службовців $[7$, с. 368$]$.

Фахівці Центру Разумкова оцінюють державну земельну політику в Україні як таку, що перебуває у стадії становлення та не відповідає повною мірою європейським та світовим критеріям і вимогам щодо належного управління земельними ресурсами. Додатково вони наводяться дані стосовно опитування громадян, які свідчать, що населення здебільшого негативно оцінює державну політику - 34,8\% (позитивно - лише $5,5 \%$ ). Водночас тільки $3,2 \%$ опитаних вважають себе добре ознайомленими 3 нормами чинного земельного законодавства, $41,4 \%$ - ознайомлені частково, більше половини $(51,8 \%)$ зовсім з ним незнайомі. Відтак $27,7 \%$ опитаних зовсім нічого не знають про державну земельну політику [8].

На думку А. Третяка, головним завданням сучасної державної політики у сфері аграрного землекористування $€$ вдосконалення земельних відносин, яке забез- 
печувало б раціональне використання та охорону продуктивних земель на основі екологізації, охорони та захисту землі, як складової навколишнього природного середовища, збереження, примноження та відтворення ії продуктивної сили як природного ресурсу [9, с. 58].

В сучасних умовах багато дискусій ведеться з приводу ринку сільськогосподарських земель, його необхідності і механізму функціонування. На сьогодні офріційно діє мораторій на продаж сільськогосподарських земель, однак, незважаючи на це, операції з продажу землі здійснюються. Цей факт свідчить про великі огріхи у законодавчій базі і сприяння державних органів у проведенні таких операцій.

Варто зазначити, що у країнах, де історично склався ринок земель, на операції купівліпродажу накладаються суттєві обмеження. У європейських державах той, хто купує землю, повинен мати відповідну сільськогосподарську кваліфрікацію, досвід роботи, проживати в цьому господарстві та працювати в ньому. Якщо фермер не обробляє землі чи використовує її неефективно, вона може бути вилучена. Практикується примусовий викуп землі в неефективного власника.

Так, у США працює механізм, за якого придбання банками землі може бути обмежене вимогою продати протягом двох років землю боржника, придбану внаслідок неповернення наданого кредиту. В Австралії для продажу землі необхідний дозвіл спеціальних органів на укладання земельних угод $[10$, с. 55$]$.

Також за кордоном держава не допускає невиправданого подрібнення ділянок або надмірної концентрації земельного ресурсу. В законодавстві Данії, Німеччини, Франції, Іспанії, Швейцарії, Норвегії та Італії встановлено максимальні розміри концентрації землі у власності юридичних чи фізичних осіб.
У Великобританії, Швеції, Голландії та інших країнах упроваджено ефективні механізми недопущення спекуляції в процесі купівлі-продажу через установлення високих податків на додану вартість, а також високих ставок податку на прибуток, що утворюється від різниці в ціні купівлі і продажу земельної ділянки.

У свою чергу, В. Дієсперов пропонує використати досвід Білорусі, у якої з нами багато спільного. Україна й Білорусь мали приблизно однакові умови на час утворення самостійних держав. За конституцією, держава надає сільськогосподарські землі, які $€$ всенародним надбанням, у користування громадянам і підприємствам, які відповідають за їх збереження і раціональне використання [11, с. 104].

Оцінюючи ситуацію, яка склалася в Україні з приводу ринку сільськогосподарських земель, можна зазначити, що не всі економісти підтримують його запровадження, вважаючи, що нині на це немає ніяких економічних підстав, а питання має більше політичне забарвлення. Вважаємо, що думка про те, ніби запровадження ринку сільськогосподарських земель може вирішити всі проблеми, є хибною. Так, із запровадженням ринку землі може зупинитися виробництво, оскільки виробники змушені будуть всі кошти вкладати в купівлю землі, а не в розвиток виробництва. Така ситуація буде на користь лише великим фінансовим групам, які вже нині не обробляють землю, а прагнуть збагатитися за рахунок її купівліпродажу [12, с. 57].

Як свідчить передовий світовий досвід, купівля-продаж землі сільськогосподарського призначення $є$ гальмом розвитку економіки. На Міжнародній конференції 3 фінансового реформування, яка відбулася в Римі у 1979 р., було зазначено, що проблеми голоду на землі виникають, передусім, під впливом купівлі-продажу сіль- 
ськогосподарських угідь. А довгострокова оренда і належне фінансове регулювання податку на землю дають змогу робити довгострокові інвестиції в передові технології $[13$, c. 47$]$.

Безумовно, питання запровадження ринку землі має бути досить виваженим. Механізм функціонування ринку має бути прозорим, а його основою має стати ефективна та дієва фінансова політика.

Зрозуміло, що ринок землі - не панацея, яка будь-що врятує економіку України. Світова фінансова криза внесла жорсткі корективи у розвиток ринку земельних відносин. Переконані, що у період кризи вводити ринок землі недоцільно, навіть шкідливо, особливо в умовах відсутності належного законодавства. Запровадження ринку сільськогосподарських земель має відбуватися 3 максимальним збереженням сільського населення і кількості господарств, які існують на сьогодні. Держава не може просто "відпустити" ринок землі і не брати в цьому процесі участі [14, с. 33].

За визначенням академіка Б.Й. Пасхавера, земельний ринок - це сукупність земельних відносин, що дають змогу реалізувати титул землевласника, щоб мати ринкову вигоду. Зокрема, під час використання землі сільськогосподарського призначення можуть забезпечити їх власникові ринковий ефект для: 1) товарного виробництва; 2) здачі в оренду; 3) продажу або застави, що можна розглядати як три форми ринку землі [15, с. 51].

Науковці виокремлюють також принципи фінансового регулювання ринку землі. Перший принцип - реалізація загальнодержавних інтересів шляхом спрямовування земельних ресурсів до тих власників, які зможуть забезпечити їх раціональне й ефрективне використання. Другий принцип полягає в єдності фрінансового регулювання ринку земель сільськогосподарсько- го призначення, тобто в єдності правової бази, методів і форм фінансового регулювання, концентрації державою контрольних функцій у спеціальному державному органі. Третій принцип передбачає послідовність фрінансового регулювання стосовно ринку сільськогосподарських земель з урахуванням тенденцій у розвитку земельних відносин, дотримання обраної моделі розвитку ринку землі відповідно до законодавчо-нормативної бази [16, с. 351].

Переконані, що роль держави має бути вирішальною, оскільки залучити у сільське господарство інвесторів можна, лише надавши їм надійні державні гарантії. Також підконтрольність державним органам 3 боку орендарів, на нашу думку, стане основним чинником у вирішенні проблем екології, продовольчої безпеки країни й ефективного використання земель.

Вважаємо, що в майбутньому оренда залишатиметься перспективною формою землекористування, однак за умови, що держава буде вести постійний контроль і сприятиме розвитку цивілізованих орендних відносин, які матимуть правове підґрунтя. Відтак, важливо стимулювати орендарів до встановлення довгострокових орендних відносин, а у випадку подовження терміну договору оренди слід перевагу надавати тому орендарю, який зберіг якість земельної ділянки.

Враховуючи той факт, що значна частина власників земельних паїв - пенсіонери, вважаємо за доцільне удосконалити правове поле спадкоємства власності на землю. Отож, слід надавати перевагу тим спадкоємцям, які будуть продовжувати сільськогосподарське виробництво. Земельну ділянку, передану спадкоємцям, які живуть у містах і не мають трудових відносин 3 господарюючим суб'єктом, необхідно переводити у державну власність. Варто заборонити передачу державних актів на володіння земельною ділянкою для жителів міст 
і осіб, які не працюють у сільськогосподарському підприємстві за місцем отримання земельного паю.

Також важливим, на наш погляд, $є$ надання орендарям і орендодавцям однакових прав, щоб, орендуючи землю, орендар протягом обумовленого часу був господарем на ній, мав самостійність у виробничій і комерційній діяльності. Для ведення господарської діяльності орендарю потрібен механізм залучення кредитів.

Необхідно передбачити обкладання за вищими ставками податку на прибуток, отриманого від продажу сільськогосподарських угідь раніше передбачених строків після їх купівлі, тобто покупець має у визначений термін вести сільськогосподарське виробництво, а не спекулювати земельними ділянками.

Особливу увагу необхідно звернути на розмір і форми виплати орендної плати. Сьогодні пропозиція оренди земельних ділянок досить висока, а попит обмежений, тому розмір її невеликий. I навіть ті господарства, які отримують значні прибутки, виплачувати високу орендну плату не поспішають. Ми погоджуємося, що орендну плату необхідно визначати як відсоток від грошової вартості земельної ділянки, але за умови, що ця вартість буде мати реальну основу - якість ґрунту і місцезнаходження.

Вважаємо, що подальший розвиток орендних відносин в Україні має здійснюватися у напрямку посилення відповідальності орендаря за виконання договірних зобов'язань, забезпечення контролю за збереженням та раціональним використанням орендованих земель. Усе це потребує створення необхідного правового поля для подальшого розвитку орендних земельних відносин та налагодження дієвого механізму їх фрінансового регулювання.

Охорона сільськогосподарських угідь передбачає формування механізмів їх захисту, серед яких важливими є: пряма фрінансова підтримка землекористувачів і компенсація частини витрат на проведення землеохоронних заходів; компенсація витрат землекористувачів на відтворення родючості ґрунту; заохочення землекористувачів до поліпшення екологічного стану землі, підвищення її родючості і виробництва екологічно чистої продукції; компенсація землекористувачам у разі завдання їм збитків під час вилучення сільськогосподарських угідь для несільськогосподарських потреб, втрат від забруднення, яке спричинило погіршення родючості земельних ділянок.

Особливої уваги з боку держави потребує і питання про цільове використання земель, оскільки віднесення земель до певної категорії і переведення їх з однієї категорії в іншу є важливим фактором організації раціонального й екологобезпечного землекористування. Так, в Україні найвищий показник розорюваності сільськогосподарських угідь, що $є$ причиною інтенсивного розвитку вітрової та водної ерозії з усіма відповідними негативними наслідками. Останніми роками відбуваються незаконні зміни цільового призначення, що призводять до зайняття навколо великих міст значних площ сільськогосподарських угідь під забудову. Тому такі процеси необхідно брати під особливий контроль, який передбачає: виявлення випадків земельних правопорушень і їх реєстрацію; відповідальність за порушення і стимулювання за поліпшення родючості ґрунту; надання консультаційних послуг.

Однією $з$ найбільш цікавих, на нашу думку, є модель ресрормування земельних відносин, яка закріплена законодавством Китаю, основною ідеєю функціонування котрої є легалізація надання землі селянським господарствам. Кооперативи та колгоспи були ліквідовані, а земля була розподілена між окремими домогосподарствами в громаді, які погоджувалися продавати 
певну кількість продукції уряду, відповідно до визначеної квоти, а залишок продукції могли споживати або продавати. Тому люди були більш зацікавлені у функціонуванні таких відносин, що призвело до більшого обсягу виробництва сільськогосподарської продукції в Китаї.

Однак слід зазначити, що під час проведення реформування виникала певна загроза передачі повноважень з центру на місцевий рівень, оскільки інтереси общин не відповідали інтересам уряду. Між індивідуальними домогосподарствами потрібно було розподілити права користування фрактично на всю територію сільськогосподарських угідь країни, в якій третина зайнятого населення безпосередньо залежала від сільського господарства.

Розглядаючи досвід Китаю щодо реформування земельних відносин, варто зазначити, що земля і донині там залишається в державній власності. Уряд країни завжди намагається покращити добробут населення, яке працює на землі, тому всі ресрорматорські пропозиції розробляються вітчизняними вченими і науковцями, які проводять обговорення та консультації 3 селянами. Слід зазначити, що аграрну реформу пристосовують до місцевих умов [17, с. 39$]$.

Відтак переконані, що грамотно побудована фінансова політика у сфері земельних відносин сприятиме зростанню добробуту населення, поліпшенню якості його життя шляхом створення сприятливих умов і задоволення його потреб.

Висновки. У регулюванні земельних відносин має бути вирішальною роль держави, оскільки вона є гарантом економічної і фінансової стабільності.

На державному рівні необхідно проводити заходи, спрямовані на створення ефрективного і регульованого обігу земель сільськогосподарського призначення з урахуванням законних інтересів власників зе- мельних ділянок, сільськогосподарських товаровиробників і держави.

Слід удосконалити фрінансове регулювання відносин власності, земельних відносин, раціонального використання земельних ділянок, а також посилити державний контроль за охороною і використанням сільськогосподарських земель.

Необхідно також створити фронд земель державної власності, що дасть змогу конструктивно впливати на процеси, пов'язані 3 обігом сільськогосподарських земель, запобігати негативним тенденціям, у тому числі спекулятивного характеру, забезпечувати стабільне землекористування і реалізацію соціально значущих інвестиційних проектів в аграрному секторі економіки.

На жаль, сучасна фрінансова політика в Україні не відповідає європейським та світовим критеріям і вимогам щодо належного управління земельними ресурсами. Тому держава має регулювати земельні відносини і здійснювати політику виважено та грамотно, оскільки земля є специфічним засобом виробництва, який потребує особливої уваги. Адже переконані, що повний лібералізм - це хаос і невизначеність, які призведуть до розквіту корупції та тіньових схем у цій важливій сфері суспільних відносин.

\section{Список використаних джерел}

1. Демчииак Н.Б. Фінансове регулювання інноваційної діяльності в Украйні : монографрія / Н.Б. Демчишак. - Львів : ЛНУ імені Івана Франка, 2016. - C. 494.

2. Бречко О. Теоретичні аспекти фінансового механізму державного регулювання економіки регіону [Електронний ресурс] / О. Бречко // Наука молода. - 2004. - № 2. - Режим доступу : http://naukamoloda.tneu.edu.ua/

3. Фінанси України: інституиійні перетворення та напрями розвитку : монографія / I.Я. Чугунов, В.І. Міщенко [mа ін.]; за ред. І.Я. Чугунова. - К. : ДННУ АФУ, 2009. - С. 848. 
4. Теорія фонансів : підручник / за ред. профр. B.М. Федосова, С.І. Юрія. - К. : Центр учбової лimepamypu, 2010. - С. 576.

5. Постанова Кабінету Міністрів України "Про затвердження питань удосконалення управління в сфрері використання та охорони земель сільськогосподарського призначення державної власності та розпорядження ними" від 7 червня 2017 р. № 413 [Електронний ресурс]. - Режим доступу : http://search.ligazakon. ua/__doc2.nsf/link1/KP170413.html.

6. Про Стратеаію сталого розвитку "Україна-2020" [Електронний ресурс] : Указ Президента України від 12.01.2015 р. № 5/2015. - Режим доcmyпy : http://zakon2.rada.gov ua/laws/show/5/2015.

7. Новаковський Л.Я. Шляхи удосконалення законодавчого забезпечення розвитку земельних відносин в Україні / Л.Я. Новаковський // Трансформація земельних відносин до ринкових умов : матеріали XI річних зборів Всеукр. конгресу вчених екон.-аграр., Київ, 26-27 лютого 2009 p. - К. : НHЦ "IAE", 2009. - C. 518.

8. Оиінка громадянами ситуації в Украіні та стану проведення реформ, ставлення до політиків та суспільних інститутів, електоральні рейтинаи [Електронний реcурс]. - Режим доступу : http://www.uceps.org/ upload/1427287523_file.pdf.

9. Третяк А. Основні напрями змін та удосконалення державної земельної політики в Україні / А. Третяк // Національна безпека і оборона. -2009 . - № 3. - С. 58-63.

10. Присяжнюк М. Земельна політика України: стан, законодавче забезпечення, стратегічне планування / М. Присяжнюк // Національна безпека і оборона. - 2009. - № 3. - С. 54-57.

11. Сільське господарство України за 2015 рік : cmam. зб. зза ред. О.М. Прокопенка. - Державна служба статистики України, 2016. - 360 c.

12. Федоров М.М. Земельна рефоорма і розвиток ринкових земельних відносин / М.М. Федоров // Економіка АПК. - 2011. - № 7. - С. 55-60.

13. Сафонова В.І. Формування ринку земель в аграрному природокористуванні та його інф- раструктури /B.I. Сафонова // Економіка АПК. 2009. - № 4. - C. 45-51.

14. Присяжнюк М.В. Законодавче забезпечення земельного ринку / М.В. Присяжнюк // Економіка АПК. - 2009. - № 9. - С. 33-35.

15. Пасхавер Б.Й. Ринок землі: світовий досвід та національна стратегія /Б.Й. Пасхавер // Економіка АПК. - 2009. - № 3. - С. 47-53.

16. Гарасим П.М. Державне регулювання ринку земель сільськогосподарського призначення / П.М. Гарасим // Трансфоормація земельнuх відносин до ринкових умов : матеріали XI річних зборів Всеукр. конгресу вчених екон.азрар., Київ, 26-27 лют. 2009 р. - К. : НHЦ “IAE", 2009. - C. 518.

17. Третяк Н. Система управління земельними ресурсами в Китаї: досвід для України / Н. Третяк // Землевпорядний вісник. - 2012. № 4. - C. $38-41$.

\section{References}

1. Demchyshak, N.B. (Eds.). (2016). Finansove rehuliuvannia innovatsiinoi diialnosti v Ukraini [Financial regulation of innovation activity in Ukraine]. Lviv: LNU imeni Ivana Franka [in Ukrainian].

2. Brechko, O. (2004). Teoretychni aspekty finansovoho mekhanizmu derzhavnoho rehuliuvannia ekonomiky rehionu [Theoretical aspects of the financial mechanism of state regulation of the region's economy]. Nauka moloda. - Young science, 2. Available at: http://naukamoloda.tneu.edu.ua/ [in Ukrainian].

3. Chugunov, I.Ya., (Eds.), Mishchenko, V.I. (2009). Finansy Ukrainy: instytutsiini peretvorennia ta napriamy rozvytku [Finances of Ukraine: institutional transformations and directions of development]. Kyiv: DNNU AFU [in Ukrainian].

4. Fedosov, V.M. Yuriy, S.I. (Eds.). (2010). Teoriia finansiv [Theory of finance]. Kyiv: Tsentr uchbovoyi literatury [in Ukrainian].

5. Pro zatverdzhennia pytan udoskonalennia upravinnia $v$ sferi vykorystannia ta okhorony zemel silskohospodarskoho pryznachennia derzhavnoi vlasnosti ta rozporiadzhennia nymy: Postanova Kabi- 
netu Ministriv Ukrainy [The Resolution of the Cabinet of Ministers of Ukraine "On Approval of issues of improvement of management in the use and protection of agricultural properties of state owned land and disposal']. (2017). Available at: http://search.ligazakon. ua/_doc2.nsf/link1/KP170413.html.

6. Pro Stratehiiu staloho rozvytku "Ukraina-2020" Ukaz Prezydenta Ukrainy [Decree of the President of Ukraine: "About the strategy of sustainable development "Ukraine 2020"]. (2015). Available at: http:// zakon2.rada.gov.ua/laws/show/5/2015.

7. Novakovskyi, L. (2009). Shliakhy udoskonalennia zakonodavchoho zabezpechennia rozvytku zemelnykh vidnosyn v Ukraini [Ways to improve legislative provision of land relations in Ukraine]. Transformatsiia zemelnykh vidnosyn do rynkovykh umov - Transformation of land relations to market conditions: Materials of the XI annual meeting of the All-Ukrainian congress of scientists of economists-agrarians. Kyiv: NTC "IAE" [in Ukrainian].

8. Otsinka hromadianamy sytuatsii v Ukraini ta stanu provedennia reform, stavlennia do politykiv ta suspilnykh instytutiv, elektoralni reitynhy [Citizens' assessment of the situation in Ukraine and the state of reform, attitudes towards politicians and public institutions, electoral ratings]. Available at: http://www.uceps.org/upload/1427287523_file.pdf.

9. Tretiak, A. (2009). Osnovni napriamy zmin ta udoskonalennia derzhavnoi zemelnoi polityky $v$ Ukraini [Basic directions of changes and improvement of state land policy in Ukraine]. Natsionalna bezpeka i oborona - National security and defense, 3, 58-63 [in Ukrainian].

10. Prysiazhniuk, M. (2009). Zemelna polityka Ukrainy: stan, zakonodavche zabezpechennia, stratehichne planuvannia [Land policy of Ukraine: status, legislative provision, strategic planning]. Natsionalna bezpeka i oborona - National security and defense, 3, 54-57 [in Ukrainian].

11. Prokopenko, O. (Eds). Silske hospodarstvo Ukrainy za 2015 rik [Agriculture of Ukraine for 2015]. Derzhavna sluzhba statystyky Ukrainy State Statistics Service of Ukraine [in Ukrainian].
12. Fedorov, M.M. (2011). Zemelna reforma i rozvytok rynkowykh zemelnykh vidnosyn [Land reform and development of market land relations]. Ekonomika APK - Economy of AIC, 7, 55-60 [in Ukrainian].

13. Safonova, V.I (2009). Formuvannia rynku zemel $v$ ahrarnomu pryrodokorystuvanni ta yoho infrastruktury [Formation of the land market in agrarian nature management and its infrastructure]. Ekonomika APK - Economy of the APC, 4, 45-51[in Ukrainian].

14. Prysiazhniuk, M. (2009). Zakonodavche zabezpechennia zemelnoho rynku [Legislative support of the land market]. Ekonomika APK - Economy of the APC, 9, 33-35 [in Ukrainian].

15. Paskhaver, B. (2009). Rynok zemli: svitovyi dosvid ta natsionalna stratehiia [Land market: world experience and national strategy]. EkonomikaAPKEconomy of the APC, 3, 47-53 [in Ukrainian].

16. Harasym, P. (2009). Derzhavne rehuliuvannia rynku zemel silskohospodarskoho pryznachennia [State regulation of the market of agricultural lands]. Transformatsiia zemelnykh vidnosyn do rynkovykh umov [Transformation of land relations to market conditions]: Materials of the XI annual meeting of the All-Ukrainian congress of economists-agrarians. Kyiv: NTC "IAE" [in Ukrainian].

17. Tretiak, N. (2012). Systema upravlinnia zemelnymy resursamy $\vee$ Kytai: dosvid dlia Ukrainy [Land management system in China: experience for Ukraine]. Zemlevporiadnyi visnyk - Land management bulletin, 4, 38-41 [in Ukrainian].

Стаття надійшла до редакції 20.09.2017. 